\title{
Incidence of Respiratory Viral Infections Detected by PCR and Real-Time PCR in Adult Patients with Community-Acquired Pneumonia: A Meta-Analysis
}

\author{
Xiaodong $\mathrm{Wu}^{\mathrm{a}}$ Qin Wang ${ }^{\mathrm{b}}$ Min Wang ${ }^{\mathrm{a}}$ Xin Su ${ }^{\mathrm{a}}$ Zheng Xing ${ }^{\mathrm{c}}$ \\ Weiyun Zhang ${ }^{\mathrm{a}} \quad \mathrm{Yi} \mathrm{Shi}^{\mathrm{a}}$ \\ a Department of Respiratory and Critical Care Medicine, Jinling Hospital, Medical School of Nanjing University, and \\ ${ }^{b}$ Department of Respiratory and Critical Care Medicine, Jinling Hospital, Clinical School of Nanjing, Second Military \\ Medical University, Nanjing, China; ${ }^{C}$ Veterinary and Biomedical Sciences, College of Veterinary Medicine, University \\ of Minnesota, Twin Cities, Saint Paul, Minn., USA
}

\section{Key Words}

Community-acquired pneumonia $\cdot$ Adults $\cdot$ Respiratory

virus · Incidence of viral infections · Meta-analysis

\begin{abstract}
Background: With the development of more rapid and sensitive detection methods based on PCR techniques, the contributions of respiratory viral infections to community-acquired pneumonia (CAP) in adult patients are being more and more recognized. Yet, up to now, there has been a lack of synthetic data that clearly demonstrates the incidence of respiratory viral infections in adult patients with CAP. Objectives: We intended to demonstrate the incidence of respiratory viral infections detected by PCR and real-time PCR in adult patients with CAP. Methods: We searched PubMed and Embase for studies providing the incidence of respiratory viral infections in adult patients with CAP. We investigated potential sources of heterogeneity by a univariant metaregression analysis and calculated the combined incidence of viral infections, viral infections mixed with other pathogens and individual respiratory virus species. Results: We eventually identified 23 eligible reports with a total number of 6,404 patients. Incidences ranged from 8.6 to $56.2 \%$
\end{abstract}

(C) 2015 S. Karger AG, Basel

$0025-7931 / 15 / 0894-0343 \$ 39.50 / 0$ for overall respiratory viral infections. We noted significant heterogeneity in incidence estimates for the incidence of viral infections (Cochran's $X^{2}=269.9, p<0.0001, I^{2}=91.8 \%$ ). The combined incidence of viral infections was $22.4 \%$ (95\% $\mathrm{Cl}=19.0-25.7)$. Incidences of viral coinfections with other pathogens ranged from 3 to $28 \%$. A high level of heterogeneity was identified as well during the estimates for incidences of coinfections $\left(x^{2}=200.9, p<0.0001, I^{2}=91.5 \%\right)$. The combined incidence of viral coinfections with other pathogens was $12.4 \%(95 \% \mathrm{Cl}=9.7-15.0)$. Our heterogeneity analyses suggested that a lower respiratory tract sample was associated with higher overall viral incidence. Moreover, the influenza virus, rhinovirus and coronavirus were the 3 most frequently detected viral pathogens in adult patients with CAP according to our study. Conclusions: Respiratory viruses are probably crucial pathogens of adult patients with CAP, with the influenza virus being the most frequent viral pathogen identified. More than half of the viral infections are characterized as mixed infections with other pathogens.

(C) 2015 S. Karger AG, Basel

Xiaodong Wu and Qin Wang contributed equally to this study.

\section{KARGER 125}

E-Mail karger@karger.com www.karger.com/res
Department of Respiratory and Critical Care Medicine, Jinling Hospital

305 East Zhongshan Road

Nanjing 210002 (China)

E-Mail shiyi56@126.com 


\section{Introduction}

Community-acquired pneumonia (CAP) as the most common cause of death due to infection in adults brings a great clinical and economic burden to the health care systems worldwide $[1,2]$. The definition of the etiology directly affects the decision concerning the clinical treatment of patients with CAP, which will finally influence the outcome for patients with CAP $[3,4]$. The bacterial causes of CAP have been well characterized, with Streptococcus pneumoniae being the most important bacterial pathogen $[5,6]$. In contrast to bacterial agents, the involvement of respiratory viral infections in adult patients with CAP has yet not been well defined.

With the development of virological diagnostic techniques, an increasing number of studies evaluating the incidence of respiratory viral infections in adult patients with CAP indicates the important contributions of respiratory viruses to CAP $[7,8]$. However, up to now, no synthetic data has clearly demonstrated the incidence of overall respiratory viral infections in adult patients with CAP and the discrepancy in the contributions to the pathogenesis of CAP across respiratory viral species.

The aim of this meta-analysis is to determine the incidence of viral infections in adult patients with CAP and demonstrate the incidence discrepancy among respiratory viral species according to previous epidemiology researches based on PCR-related techniques.

\section{Methods}

\section{Search Strategy}

In July 2013, we conducted a systematic search utilizing PubMed and Embase search engines for citations published from January 1, 2000 to July 19, 2013. The initial search was undertaken using free-word, keyword and MeSH searches for 'communityacquired pneumonia', 'virus', 'adult' and 'PCR'. Two researchers (X.W. and Q.W.) independently searched the titles and abstracts identified initially on screen for the selection of the potential studies. We also searched the reference lists of the included studies. When needed, we contacted the authors to obtain missing or additional information. We settled any discrepancies through discussion with a third researcher (M.W.).

\section{Inclusion/Exclusion Criteria}

Studies had to meet the following criteria for inclusion: (1) patients were $\geq 16$ years old; (2) studies clearly stated the definition of CAP; (3) studies provided the incidence of respiratory viral infections in CAP patients; (4) respiratory viruses were detected by highly sensitive techniques (PCR and real-time PCR); (5) at least $90 \%$ of the samples collected were used for viral detection; (6) the full paper was available in the English literature.
Studies were excluded if they focused on patients in an immunosuppressed state, such as in the case of patients with solid organ or bone marrow transplantations, AIDS or receiving chemotherapy or taking other immunosuppressive drugs etc.

\section{Quality Assessment and Data Extraction}

Two reviewers independently assessed the quality of all included studies using score quality criteria based on the principles of the quality assessment of observational studies (as shown in online suppl. table 1; see www.karger.com/doi/10.1159/000369561 for all online suppl. material). The relevant trail characteristics were independently extracted by 2 reviewers (X.W. and Q.W.), and any discrepancies were solved with complete agreement through rechecking the source papers and discussion. Data extraction for each study was done according to a standardized form designed by us to capture and record all relevant information required for analysis. For each study, 2 reviewers extracted the data independently, cross-checked with each other and resolved disagreements through discussion. For all included studies, the following information was recorded: author, year of publication, country, number of patients, number of respiratory virus species detected, viral detection method, specimen collected for viral detection, number of patients with viral infections and number of patients with mixed infections by viruses and other pathogens.

\section{Statistical Analysis}

According to the expected heterogeneity across studies, the combined incidence of respiratory viral infections with $95 \%$ was calculated with a DerSimonian-Laird random-effects model [9]. Statistical heterogeneity was tested with Cochran's $\chi^{2}$ and quantified with the $\mathrm{I}^{2}$ statistic (30-60\% for moderate heterogeneity; 50$90 \%$ for substantial heterogeneity; $75-100 \%$ for considerable heterogeneity) [10]. In order to reduce the heterogeneity across studies and perform further analysis, a subgroup analysis was required. We further investigated potential sources of heterogeneity by metaregression analysis. Factors examined individually in univariable models were the sample type used for viral detection (by comparing a lower respiratory tract specimen with an upper respiratory tract specimen), time span of patient enrollment, geographical region, number of viral species detected and number of viral detection methods. We did all analyses in Stata (version 12.1, StataCorp LP, College Station, Tex., USA) with the commands 'metan' (for random-effects meta-analysis), 'metareg' (for metaregression) and 'metainf (for sensitivity analysis).

\section{Results}

A total of 768 records were returned during our searches. After initial screening and removal of duplicates, we reviewed 76 papers in full text. Finally, 23 studies $(\mathrm{n}=$ 6,404) published between February 2001 and July 19, 2013 were included as eligible reports for our further analysis (fig. 1, table 1). The quality score of those 23 reports is listed in table 1 . Ten of the 23 reports achieved a score $\geq 7$, and the other 13 reports scored between 4 and 6 . Of the 23 reports, 2 were conducted in adult outpatients 
Fig. 1. Flowchart of the selection of the studies.

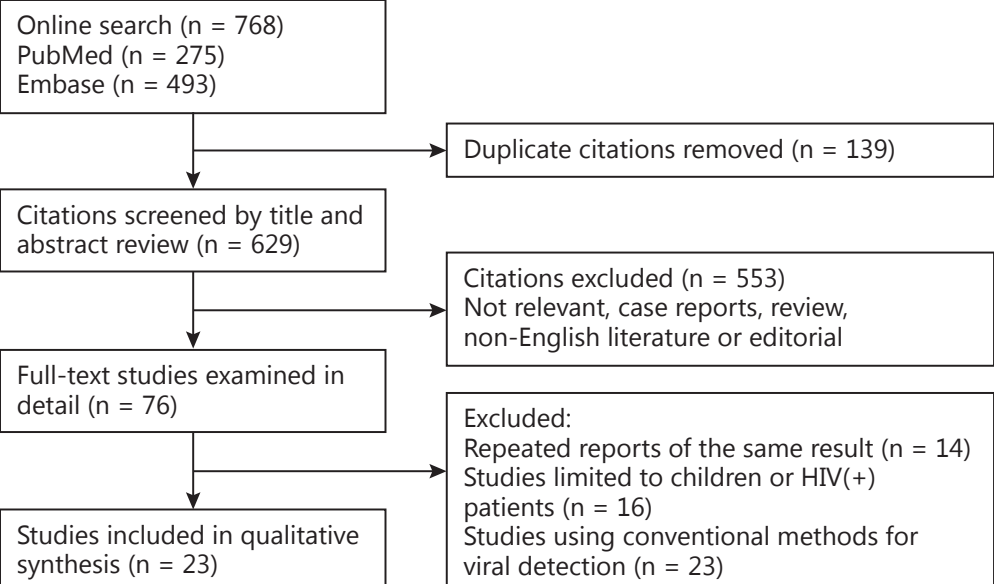

Table 1. Summarized characteristics of the studies included in the meta-analysis

\begin{tabular}{|c|c|c|c|c|c|c|}
\hline Author & $\begin{array}{l}\text { Year of } \\
\text { publication }\end{array}$ & Viral identification method & Specimens & $\begin{array}{l}\text { Viral } \\
\text { species, } \mathrm{n}\end{array}$ & $\begin{array}{l}\text { Patients, } \\
\mathrm{n}\end{array}$ & $\begin{array}{l}\text { Quality } \\
\text { score }^{1}\end{array}$ \\
\hline Takahashi et al. [15] & 2013 & PCR & Nasopharyngeal swabs & 13 & 167 & 9 \\
\hline Luchsinger et al. [31] & 2013 & Culture, IFA, serology, PCR & Serum, sputum, nasopharyngeal aspirate & 10 & 356 & 6 \\
\hline Wiemken et al. [13] & 2013 & PCR & Nasopharyngeal swabs & 12 & 393 & 7 \\
\hline Viasus et al. [14] & 2013 & RT-PCR & Nasopharyngeal swabs or BALF & 13 & 747 & 8 \\
\hline Musher et al. [16] & 2013 & PCR & Nasopharyngeal swabs & 7 & 259 & 6 \\
\hline Huijskens et al. [17] & 2013 & RT-PCR & Throat swabs, sputum & 14 & 408 & 8 \\
\hline Yin et al. [11] & 2012 & RT-PCR & Throat swabs, sputum & 13 & 215 & 5 \\
\hline Sangil et al. [18] & 2012 & PCR & Nasopharyngeal swabs, sputum & 12 & 131 & 6 \\
\hline Choi et al. [19] & 2012 & RT-PCR & Nasopharyngeal aspirates, BALF & 16 & 64 & 6 \\
\hline Johansson et al. [7] & 2010 & RT-PCR & Nasopharyngeal samples & 16 & 184 & 5 \\
\hline Cilloniz et al. [20] & 2011 & PCR, serology & Nasopharyngeal swabs, serum & 14 & 362 & 4 \\
\hline Shibli et al. [21] & 2010 & PCR, serology & Nasopharyngeal swabs, serum & 8 & 126 & 5 \\
\hline Mermond et al. [22] & 2010 & serology, PCR, IFA & $\begin{array}{l}\text { Serum, nasopharyngeal swabs, TBA, } \\
\text { BALF or PSB samples }\end{array}$ & 7 & 137 & 5 \\
\hline Lieberman et al. [23] & 2010 & RT-PCR & $\begin{array}{l}\text { Oropharyngeal swabs, nasopharyngeal } \\
\text { swabs and nasopharyngeal washing }\end{array}$ & 12 & 183 & 9 \\
\hline Cao et al. [12] & 2010 & RT-PCR & Sputum and throat swabs & 16 & 197 & 6 \\
\hline Diederen et al. [24] & 2009 & PCR, serology & Throat swabs, sputum & 10 & 242 & 5 \\
\hline Johnstone et al. [25] & 2008 & direct fluorescent antigen tests, RT-PCR & Nasopharyngeal swabs & 13 & 193 & 7 \\
\hline Jennings et al. [26] & 2008 & PCR, serology, IFA, culture & Nasopharyngeal swabs, serum & 11 & 304 & 9 \\
\hline Charles et al. [27] & 2008 & PCR & Nose and throat swabs & 8 & 885 & 5 \\
\hline Saito et al. [32] & 2006 & PCR, serology & Sputum and serum & 5 & 232 & 7 \\
\hline Angeles et al. [28] & 2006 & RT-PCR, IFA, culture & Nasopharyngeal swabs & 12 & 198 & 6 \\
\hline Templeton et al. [29] & 2005 & RT-PCR & Throat washes and throat swab specimens & 12 & 105 & 8 \\
\hline Macfarlane et al. [30] & 2001 & PCR, serology, culture & Throat swabs, serum & 7 & 316 & 7 \\
\hline
\end{tabular}

$\mathrm{BALF}=$ Bronchial alveolar lavage fluid; IFA = indirect immunofluorescence assay; PSB = protected specimen brush; RT-PCR = real-time polymerase chain reaction; $\mathrm{TBA}=$ tracheobronchial aspirate.

${ }^{1}$ Maximum score $=9$. 


\begin{tabular}{|c|c|c|c|c|c|c|}
\hline Study & Year & \multicolumn{3}{|l|}{ Country } & \multirow[t]{2}{*}{$\begin{array}{l}\text { Incidence estimate } \\
\text { and } 95 \% \mathrm{CI}\end{array}$} & $\begin{array}{l}\text { Weight, } \\
\%\end{array}$ \\
\hline \multicolumn{6}{|c|}{ Both outpatients and inpatients } & \\
\hline Macfarlane et al. [30] & 2001 & UK & $\rightarrow$ & & $0.19(0.15-0.24)$ & 4.58 \\
\hline Templeton et al. [29] & 2005 & The Netherlands & & $\longrightarrow$ & $0.56(0.47-0.66)$ & 3.56 \\
\hline Saito et al. [32] & 2006 & Japan & $\rightarrow-$ & & $0.16(0.12-0.21)$ & 4.52 \\
\hline Luchsinger et al. [31] & 2013 & Chile & & & $0.22(0.18-0.27)$ & 4.59 \\
\hline \multicolumn{3}{|c|}{ Subtotal $\left(I^{2}=94.7 \%, p=0.000\right)$} & & 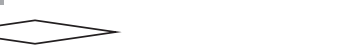 & $0.28(0.16-0.39)$ & 17.25 \\
\hline \multicolumn{7}{|l|}{ Inpatients } \\
\hline Angeles et al. [28] & 2006 & Spain & $-\rightarrow$ & & $0.13(0.08-0.18)$ & 4.53 \\
\hline Jennings et al. [26] & 2008 & New Zealand & & $\rightarrow-$ & $0.29(0.24-0.34)$ & 4.64 \\
\hline Charles et al. [27] & 2008 & Australia & $\rightarrow$ & & $0.15(0.13-0.17)$ & 4.85 \\
\hline Johnstone et al. [25] & 2008 & Canada & $\rightarrow$ & & $0.19(0.14-0.25)$ & 4.37 \\
\hline Diederen et al. [24] & 2009 & The Netherlands & $\Rightarrow$ & & $0.21(0.16-0.27)$ & 4.44 \\
\hline Lieberman et al. [23] & 2010 & Israel & & $\longrightarrow-$ & $0.32(0.25-0.38)$ & 4.14 \\
\hline Mermond et al. [22] & 2010 & New Caledonia & - & - & $0.21(0.14-0.28)$ & 4.12 \\
\hline Shibli et al. [21] & 2010 & Israel & & $\longrightarrow$ & $0.33(0.25-0.42)$ & 3.83 \\
\hline Johansson et al. [7] & 2010 & Sweden & & $\longrightarrow-$ & $0.29(0.23-0.36)$ & 4.17 \\
\hline Cilloniz et al. [20] & 2011 & Spain & -- & & $0.09(0.06-0.11)$ & 4.79 \\
\hline Choi et al. [19] & 2012 & Korea & & $\longrightarrow$ & $0.41(0.29-0.53)$ & 3.04 \\
\hline Sangil et al. [18] & 2012 & Spain & & $\longrightarrow-$ & $0.36(0.28-0.44)$ & 3.83 \\
\hline Musher et al. [16] & 2013 & USA & $-\infty-$ & & $0.16(0.12-0.21)$ & 4.56 \\
\hline Viasus et al. [14] & 2013 & Spain & - & & $0.17(0.14-0.19)$ & 4.81 \\
\hline Huijskens et al. [17] & 2013 & The Netherlands & & $\rightarrow-$ & $0.29(0.24-0.33)$ & 4.58 \\
\hline Wiemken et al. [13] & 2013 & USA & & & $0.23(0.19-0.28)$ & 4.61 \\
\hline Takahashi et al. [15] & 2013 & Vietnam & $\rightarrow-$ & & $0.16(0.11-0.22)$ & 4.37 \\
\hline \multicolumn{3}{|c|}{ Subtotal $\left(\mathrm{I}^{2}=90.8 \%, \mathrm{p}=0.000\right)$} & & & $0.23(0.19-0.26)$ & 73.51 \\
\hline \multicolumn{7}{|l|}{ Outpatients } \\
\hline Cao et al. [12] & 2010 & China & $\rightarrow-$ & & $0.10(0.06-0.14)$ & 4.62 \\
\hline & 2012 & China & $-\bullet-$ & & $0.11(0.07-0.15)$ & 4.62 \\
\hline \multicolumn{3}{|c|}{ Subtotal $\left(I^{2}=0.0 \%, p=0.724\right)$} & $\diamond$ & & $0.10(0.07-0.13)$ & 9.24 \\
\hline \multicolumn{3}{|c|}{ Overall $\left(\mathrm{I}^{2}=91.8 \%, \mathrm{p}=0.000\right)$} & & & $0.22(0.19-0.26)$ & 100.0 \\
\hline \multicolumn{3}{|c|}{ Weights are from random-effects analysis. } & & 0.657 & & \\
\hline
\end{tabular}

Fig. 2. The combined incidence of viral infections in adult patients with CAP.

with CAP $[11,12], 17$ in adult inpatients with CAP [7, 13-28] and 4 in both outpatients and inpatients with CAP [29-32]. Nine reports were carried out in Europe (4 in Spain, 3 in the Netherlands, 1 in the UK and 1 in Sweden) $[7,14,17,18,20,24,28-30], 5$ in Southeast Asia (2 in China, 1 in Japan, 1 in Korea and 1 in Vietnam) [11, 12, 15, 19, 32], 3 in Australia [22, 26, 27], 4 in America (2 in the USA, 1 in Canada and 1 in Chile) $[13,16,25,31]$ and 2 in Israel [21,23]. Moreover, respiratory viral detection in 12 studies was solely based on PRC/real-time PCR [7, 11-19, 23, 27, 29], and viral detection in the other studies was based on a combination of PCR/real-time PCR and conventional methods [20-22, 24-26, 28, 30-32].
Incidence estimates of respiratory viruses in patients with CAP ranged from 8.6 to $56.2 \%$ (fig. 2); heterogeneity was considerable $\left(\chi^{2}=269.9, \mathrm{p}<0.0001, \mathrm{I}^{2}=91.8 \%\right)$. The random-effects combined incidence was $22.4 \%$ (95\% CI $\left.=19.0-25.7, \mathrm{I}^{2}=91.8 \%\right)$. Considering the high level of heterogeneity, we further conducted a subgroup analysis for the separate calculation of combined incidences according to the types of patients (inpatients, outpatients and mixed patients), time span of patient enrollment ( 1 year vs. $>1$ year), economic level of the countries (developed vs. developing countries), PCR methods (routine PCR vs. real-time PCR) or according to the region where each report was conducted (Europe, 
Table 2. Combined incidence estimates of viral infections in adult patients with CAP by geographical region

\begin{tabular}{lllrrr}
\hline Region & $\begin{array}{l}\text { Incidence of } \\
\text { respiratory viral } \\
\text { infections, } \%\end{array}$ & $95 \% \mathrm{CI}$ & \multicolumn{1}{c}{$\begin{array}{l}\mathrm{I}^{2}, \\
\%\end{array}$} & $\chi^{2}$ & $\mathrm{p}$ \\
\hline Europe & 24.7 & $18.0-31.5$ & 95.1 & 162.6 & 0.000 \\
Southeast Asia & 16.6 & $10.5-22.8$ & 85.1 & 26.9 & 0.000 \\
Australia & 21.5 & $12.2-30.8$ & 91.9 & 24.6 & 0.000 \\
America & 20.4 & $17.1-23.8$ & 52.9 & 6.4 & 0.095 \\
Middle East & 32.4 & $27.1-37.6$ & 0.0 & 0.1 & 0.763 \\
\hline
\end{tabular}

\begin{tabular}{|c|c|c|c|}
\hline & $\begin{array}{l}\text { Metaregression } \\
\text { coefficient }\end{array}$ & $95 \% \mathrm{CI}$ & $\mathrm{p}$ \\
\hline \multicolumn{4}{|c|}{ Incidence of respiratory viral infections in patients with CAP } \\
\hline LRI specimens & 0.091 & 0.001 to 0.18 & 0.048 \\
\hline Region & 0.002 & -0.04 to 0.04 & 0.904 \\
\hline Number of viral species detected & 0.008 & -0.01 to 0.02 & 0.273 \\
\hline Number of viral detection methods & -0.019 & -0.10 to 0.06 & 0.620 \\
\hline Time span & -0.017 & -0.05 to 0.02 & 0.350 \\
\hline \multicolumn{4}{|c|}{ Incidence of respiratory viral coinfections with other pathogens in patients with CAP } \\
\hline LRI specimens & 0.049 & -0.03 to 0.13 & 0.198 \\
\hline Region & -0.0004 & -0.03 to 0.03 & 0.975 \\
\hline Viral species detected, $\mathrm{n}$ & 0.006 & -0.01 to 0.02 & 0.314 \\
\hline Viral detection methods, $\mathrm{n}$ & -0.004 & -0.05 to 0.04 & 0.843 \\
\hline Time span, year & 0.0008 & -0.10 to 0.10 & 0.986 \\
\hline
\end{tabular}

LRI specimens, i.e. lower respiratory tract specimens, were collected for viral detection.
Table 3. Univariate metaregression for the incidence of viral infections and viral infections mixed with other pathogens in adult patients with CAP
Southeast Asia, Australia, America and the Middle East), as shown in table 2 . The combined incidence of respiratory viruses was $10.2 \%\left(95 \% \mathrm{CI}=7.3-13.1, \mathrm{I}^{2}=0 \%\right)$ in outpatients $[11,12], 22.7 \%\left(95 \%=19.0-26.4, \mathrm{I}^{2}=90.8 \%\right)$ in inpatients $[7,13-28,31,32]$ and $27.7 \%(95 \%=16.4-$ $\left.39.0, \mathrm{I}^{2}=94.7 \%\right)$ in mixed patients $[29,30]$. In the subgroup analysis according to regions, the combined incidence was highest in the Middle East $(32 \%, 95 \%$ CI = $\left.27-38, \mathrm{I}^{2}=0 \%\right)[21,23]$ and lowest in Southeast Asia $\left(16.6 \%, 95 \% \mathrm{CI}=10.5-22.8, \mathrm{I}^{2}=85.1 \%\right)[11,12,15,19$, $32]$. The combined incidence was $24.3 \%(95 \% \mathrm{CI}=20.3-$ $\left.28.3, \mathrm{I}^{2}=92.7 \%\right)$ and $15.8 \%\left(95 \% \mathrm{CI}=10.4-21.3, \mathrm{I}^{2}=\right.$ $84.2 \%)$ in developed countries and developing countries, respectively. In the subgroup analysis stratified by the time span of the studies, the combined incidence of respiratory viruses in the studies covering 1 year and $>1$ year was $23.6 \%\left(95 \% \mathrm{CI}=22.1-25.1, \mathrm{I}^{2}=92.6 \%\right)$ and $24.3 \%\left(95 \% \mathrm{CI}=22.5-26.2, \mathrm{I}^{2}=96.9 \%\right)$, respectively. In addition, considering that real-time PCR is more sensitive than routine PCR, which might lead to the significant heterogeneity in our study, we further performed a subgroup analysis stratified by PCR methods (routine PCR vs. real-time PCR). The combined incidence of respiratory viruses was $20.9 \%\left(95 \% \mathrm{CI}=17.1-24.6, \mathrm{I}^{2}=\right.$ $89.2 \%)$ in studies using routine PCR and $24.7 \%$ (95\% $\left.\mathrm{CI}=18.1-31.3, \mathrm{I}^{2}=94.3 \%\right)$ in studies using real-time PCR.

Considering that the subgroup analysis cannot explain all sources of heterogeneity among the incidence of respiratory viruses in patients with CAP, we further carried out a univariate metaregression analysis (table 3 ) and found that the viral incidence was higher in studies in which lower respiratory tract specimens were collected for viral detection $(\mathrm{p}=0.048)$ than in those in which only upper respiratory tract specimens were collected for viral detection. Additionally, we did a sensitivity analysis and found that the study by Cilloniz et al. [20] might have contributed to the heterogeneity. However, the recombined incidence of respiratory viruses after omission of that study was $23.0 \%$ (95\% CI $\left.=19.7-26.3, \mathrm{I}^{2}=90.5 \%\right)$, which was similar to the combined incidence before omission. 


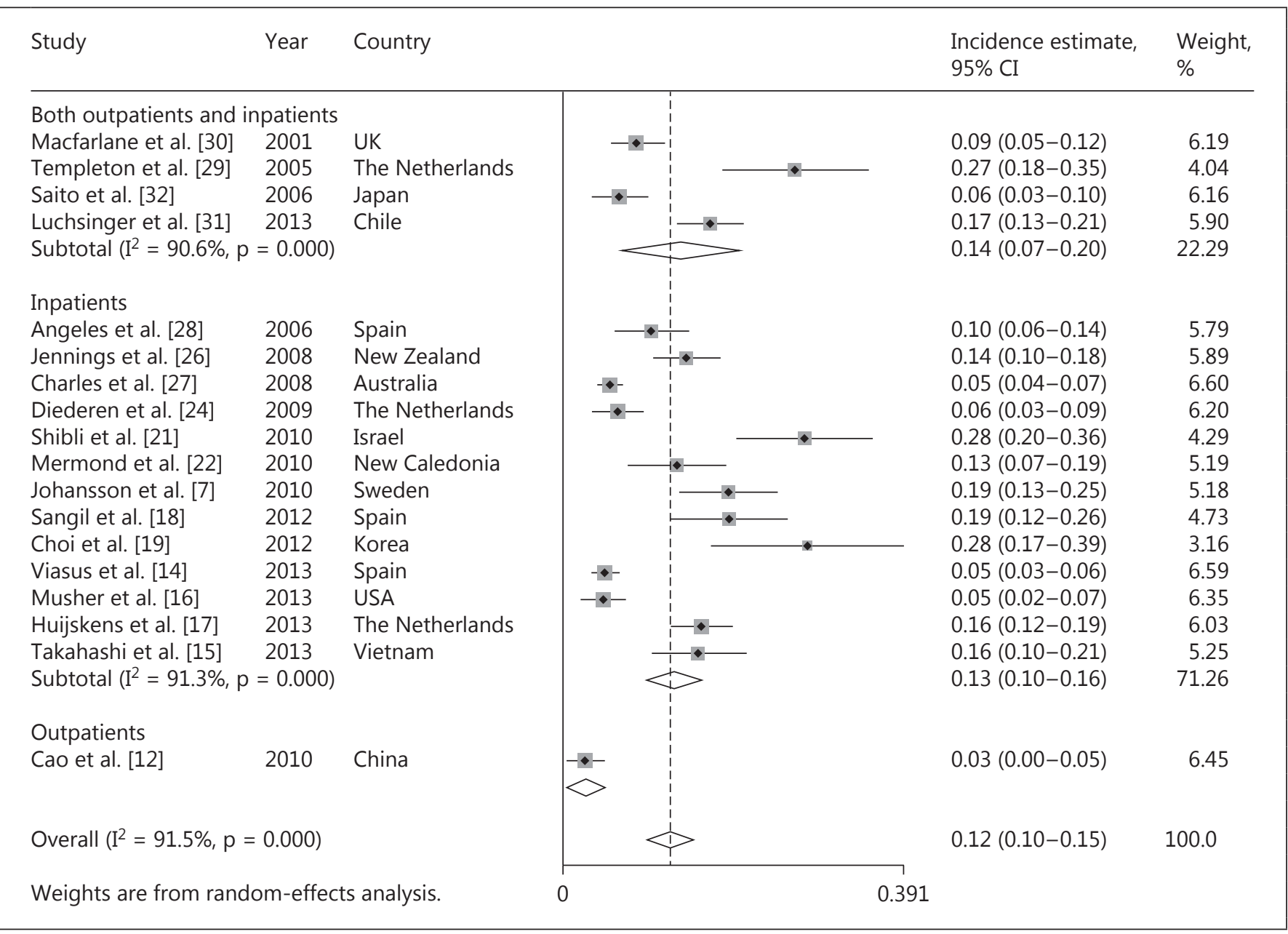

Fig. 3. The combined incidence of viral infections mixed with other pathogens in adult patients with CAP.

Of the 23 reports, 18 studies [7, 12, 14-22, 24, 26-32] provided data for the calculation of the coinfection incidences of respiratory viruses with other pathogens $(n=$ 5,058 ). As shown in figure 3 , the incidence estimates of coinfections ranged from 3 to $28 \%$; heterogeneity was considerable $\left(\chi^{2}=200.9, \mathrm{p}<0.0001, \mathrm{I}^{2}=91.5 \%\right)$. The combined overall incidence of coinfections of respiratory viruses with other pathogens (mainly bacteria) was $12.4 \%$ (95\% CI $\left.=9.7-15.0, \mathrm{I}^{2}=91.5 \%\right)$. Due to the high level of heterogeneity, the subgroup analysis was performed according to the patient types, economic level of the countries and regions where the studies were performed, as mentioned above. The combined incidence of coinfections was $12.9 \%\left(95 \% \mathrm{CI}=9.7-16.1, \mathrm{I}^{2}=91.3 \%\right)$ in inpatients with CAP $[7,14-19,21,22,24,26-28]$ and $13.7 \%\left(95 \% \mathrm{CI}=7.1-20.3, \mathrm{I}^{2}=90.6 \%\right)$ in mixed patients with CAP [29-32]. Since only 1 study provided the inci- dence of coinfections in outpatients with CAP [12], a combined estimate was not performed. In the subgroup analysis stratified by the time span of the studies, the combined incidence of respiratory viruses in the studies covering 1 year and $>1$ year was $12.5 \%(95 \% \mathrm{CI}=9.2$ $\left.15.7, \mathrm{I}^{2}=91.3 \%\right)$ and $12.4 \%\left(95 \% \mathrm{CI}=9.7-15.0, \mathrm{I}^{2}=\right.$ 94.1\%), respectively. Additionally, the combined incidence of coinfections was $12.3 \%\left(95 \% \mathrm{CI}=9.3-15.3, \mathrm{I}^{2}=\right.$ $91.1 \%)$ and $12.4 \%\left(95 \% \mathrm{CI}=9.7-15.0, \mathrm{I}^{2}=93.6 \%\right)$ in developed countries and developing countries, respectively. Moreover, the combined incidence of coinfections was similar between Europe [7, 14, 17, 18, 24, 28-30], Southeast Asia [12, 15, 19, 32] and Australia [22, 26, 27] $(12.9,11.4$ and $10.6 \%$, respectively) as shown in table 4 . In the individual variable metaregression analysis, none of the factors we explored further was significantly associated with heterogeneity (table 3 ). Moreover, in the sen- 


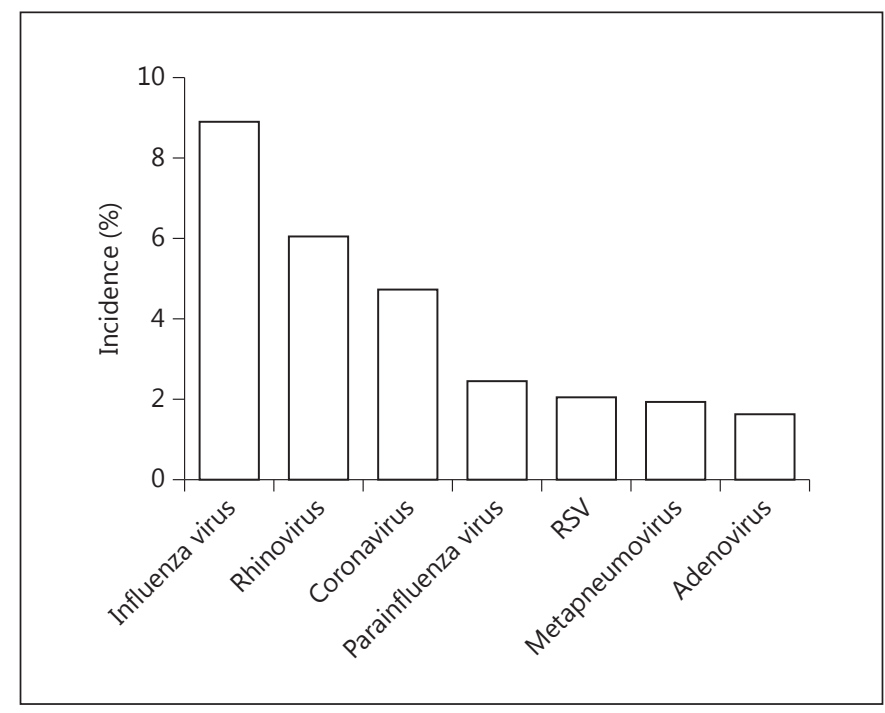

Fig. 4. Discrepancies of the combined incidence across the common respiratory viral species. RSV $=$ Respiratory syncytial virus.

sitivity analysis, none of the studies were identified as contributing to the heterogeneity.

Taking into account the discrepancy of incidence among respiratory virus species, we extracted the incidence of the 7 most common respiratory viral species for an individual combined incidence estimate. As shown in figure 4 and table 5, the 3 most frequently detected viruses were the influenza virus $\left(8.9 \%, 95 \% \mathrm{CI}=7-11, \mathrm{I}^{2}=\right.$ $79.7 \%)$, rhinovirus $\left(6.0 \%, 95 \% \mathrm{CI}=4-8, \mathrm{I}^{2}=87.4 \%\right)$ and coronavirus $\left(4.7 \%, 95 \% \mathrm{CI}=3-7, \mathrm{I}^{2}=77.4 \%\right)$. However, the respiratory syncytial virus, metapneumovirus and adenovirus were less commonly detected.

\section{Discussion}

Our meta-analysis of the incidence of respiratory viral infections in adult patients with CAP identified 23 studies of 6,404 individuals. At present, there is a lack of quantitative syntheses of studies regarding the incidence of respiratory viral infections in adult patients with CAP worldwide. Our main finding is that respiratory viruses contribute to approximately $1 / 5$ infections in adult patients presenting with CAP, highlighting their role in the pathogenesis of CAP. Furthermore, the influenza virus is the most frequent respiratory viral etiology in adult patients with CAP.

The incidence of viral infections in adult outpatients with CAP is lower than that in adult inpatients (10 vs. $22 \%$ ) as demonstrated in the subgroup analysis, implying

Viral Infections in Adult Patients with

CAP
Table 4. Combined incidence estimates of viral infections mixed with other pathogens in adult patients with CAP by geographical region

\begin{tabular}{llrrrr}
\hline Region & $\begin{array}{l}\text { Incidence of viral } \\
\text { infections mixed with } \\
\text { other pathogens, \% }\end{array}$ & $95 \% \mathrm{CI}$ & $\mathrm{I}^{2}, \%$ & $\chi^{2}$ & $\mathrm{p}$ \\
\hline Europe & 12.9 & $8.6-17.3$ & 91.4 & 81.7 & 0.000 \\
Southeast Asia & 11.4 & $4.2-18.6$ & 91.0 & 22.2 & 0.000 \\
Australia & 10.6 & $3.8-17.3$ & 91.0 & 22.2 & 0.000 \\
America & 10.7 & $0.0-22.6$ & 96.2 & 26.5 & 0.000 \\
Middle East & 27.8 & $20.0-35.6$ & - & - & - \\
\hline
\end{tabular}

Table 5. Discrepancies of the combined incidence across the common respiratory viral species

\begin{tabular}{llllrl}
\hline Viral species & $\begin{array}{l}\text { Incidence, } \\
\%\end{array}$ & $95 \% \mathrm{CI}$ & \multicolumn{1}{l}{$\begin{array}{l}\mathrm{I}^{2}, \\
\%\end{array}$} & \multicolumn{1}{l}{$\chi^{2}$} & $\mathrm{p}$ \\
\hline Influenza virus & 8.9 & $7.1-10.6$ & 79.7 & 83.6 & 0.000 \\
Rhinovirus & 6.0 & $4.3-7.7$ & 87.4 & 111.2 & 0.000 \\
Coronavirus & 4.7 & $2.9-6.6$ & 77.4 & 39.8 & 0.000 \\
Parainfluenza virus & 2.4 & $1.4-3.4$ & 75.9 & 49.7 & 0.000 \\
RSV & 2.0 & $1.3-2.7$ & 74.4 & 62.4 & 0.000 \\
Metapneumovirus & 1.9 & $1.0-2.8$ & 48.5 & 15.5 & 0.049 \\
Adenovirus & 1.6 & $0.9-2.4$ & 65.9 & 29.4 & 0.001 \\
\hline
\end{tabular}

$\mathrm{RSV}=$ Respiratory syncytial virus.

that viral infections could aggravate the condition of patients presenting with pneumonia. Moreover, the combined incidence of viral infections mixed with other pathogens (mainly bacteria) is $12 \%$ in our study, constituting more than half of the total viral infections in adult patients with CAP. Evidence from several studies illustrated that viral infections made hosts susceptible to secondary bacterial infections because mucosal barriers in the respiratory tracts were impaired during previous viral infections $[33,34]$, which led to the bacterial invasions becoming more facile. There is evidence as well, although sparse, suggesting that mixed viral-bacterial infections would generate a severer inflammatory status and clinical presentation than individual bacterial or viral infections $[24,26,35]$. Severe fatal pneumonia can be caused by concomitant infection with the influenza virus and Staphylococcus aureus in both children and adults [36-38]. Moreover, in 1 pneumonia study focused on adults, rhinovirus-pneumococcal coinfections correlated with severe pneumonia and raised mortality $[24,26,35]$. Therefore, our results would be helpful for clinicians to better recognize the burden of viral infections and mixed viral-bacterial infections on adult patients presenting with CAP. 
The influenza virus is the most frequent viral pathogen detected in adult patients with CAP as our study demonstrates, which is inconsistent with the fact that the respiratory syncytial virus is the leading viral pathogen in pediatric patients with CAP [39-42]. Influenza vaccination has been previously proven to be efficient in preventing influenza viral infections especially during a pandemic influenza period [43]. Furthermore, several studies which enrolled patients with a chronic lung disease indicated that an influenza vaccination significantly reduced the incidence of pneumonia or acute exacerbations in those patients [44]. Therefore, a regular and routine influenza vaccination of patients with chronic lung disease would be needed to lower the burden of pneumonia caused by the influenza virus. Moreover, newly developed anti-influenza virus drugs (neuraminidase inhibitors, such as oseltamivir and zanamivir), which have established roles in the early treatment of influenza infections through reducing the median time to the resolution of the symptoms and the risk of pneumonia [45], provided an efficient weapon for clinicians to manage patients with viral pneumonia caused by the influenza virus.

Respiratory viruses have been realized as a common etiology in patients with CAP, especially children with CAP. However, conventional virological diagnostic techniques such as serology, immunofluorescence and culture have been underestimating the contribution of viruses to the pathogenesis of CAP [46, 47], especially in adult patients, due to their low sensitivity and narrow application. Owing to the development of more rapid and sensitive detection methods (PCR and real-time PCR), the viral diagnosis is largely improved, particularly through the combined application of these methods with conventional detection techniques [7]. Lots of previous studies evaluating the role of respiratory viruses in adult patients with CAP have been reported; nevertheless, there are discrepancies in the detection methods used for viral diagnosis across those studies. Therefore, we only included studies applying sensitive detection techniques (PCR and real-time PCR) for viral diagnosis in our further meta-analysis to reduce possible heterogeneity along with obtaining quantitative syntheses of original data.

Nevertheless, significant heterogeneity was still found during the meta-analysis and subgroup analysis. Our following heterogeneity analyses generated 1 potentially important finding, namely that lower respiratory tract specimens were associated with higher overall viral incidence. This may be because the molecular detection of the virus in lower respiratory tract specimens was more sensitive than the one in upper respiratory tract specimens. The potential implication of this result is that the presence of viral nucleic acids, detected by PCR of lower respiratory tract samples, implies stronger evidence of the infection by virus. However, no relation was identified between the incidence of coinfection and the lower respiratory tract specimens, which might be explainable. As we could speculate, discrepancies of both bacterial diagnostic and viral detection would lead to a significant heterogeneity of the incidence of coinfection. Caution is necessary when combined incidence estimates are used due to the significant heterogeneity, and further surveys are required for the standardization of the specimen collection, specimen quality, PCR primers and PCR reaction conditions during respiratory viral etiology diagnosis.

Our study had several limitations. First, we excluded many studies in the non-English literature and thus lost the raw data of those reports. Second, studies included in our meta-analysis were predominantly performed in high-income and middle-income regions. Therefore, fundamental incidence data for low-income countries are missing. Third, due to the lack of associated original data we were unable to explore the relationship between clinical severity of pneumonia and causative viral pathogens.

Thus, our study suggests that approximately one fifth of adult patients with CAP are infected by respiratory viruses, more than half of those viral infections are characterized as mixed infections with other pathogens, and influenza virus is the leading viral pathogen in adult patients with CAP, although there is significant heterogeneity during the quantitative synthesis of the raw data. Further surveys are required to establish a standardization of specimen management and detection processes for viral diagnostics.

\section{Financial Disclosure and Conflicts of Interest}

The authors have no support or funding to report. They declare that there are no competing interests.

References

1 WHO: The top 10 causes of death. 2013. http://who.int/mediacentre/factsheets/fs310/ en/.

2 Lim WS, Baudouin SV, George RC, Hill AT, Jamieson C, Le Jeune I, Macfarlane JT, Read RC, Roberts HJ, Levy ML, Wani M, Woodhead MA: BTS guidelines for the management of community-acquired pneumonia in adults: update 2009. Thorax 2009;64(suppl 3):iiil-iii55. 
- 3 Mandell LA, Wunderink RG, Anzueto A, Bartlett JG, Campbell GD, Dean NC, Dowell SF, File TM Jr, Musher DM, Niederman MS, Torres A, Whitney CG: Infectious Diseases Society of America/American Thoracic Society consensus guidelines on the management of community-acquired pneumonia in adults. Clin Infect Dis 2007;44(suppl 2):S27-S72.

4 Durrington HJ, Summers C: Recent changes in the management of community-acquired pneumonia in adults. BMJ 2008;336:14291433.

5 Bartlett JG: Diagnostic tests for agents of community-acquired pneumonia. Clin Infect Dis 2011;52(suppl 4):S296-S304.

-6 Moran GJ, Rothman RE, Volturo GA: Emergency management of community-acquired bacterial pneumonia: what is new since the 2007 Infectious Diseases Society of America/ American Thoracic Society guidelines. Am J Emerg Med 2013;31:602-612.

7 Johansson N, Kalin M, Tiveljung-Lindell A, Giske CG, Hedlund J: Etiology of community-acquired pneumonia: increased microbiological yield with new diagnostic methods. Clin Infect Dis 2010;50:202-209.

$>8$ Tiveljung-Lindell A, Rotzen-Ostlund M, 19 Gupta S, Ullstrand R, Grillner L, ZweygbergWirgart B, Allander T: Development and implementation of a molecular diagnostic platform for daily rapid detection of 15 respiratory viruses. J Med Virol 2009;81:167-175.

-9 DerSimonian R, Laird N: Meta-analysis in clinical trials. Control Clin Trials 1986;7:177-188.

10 Higgins JP, Thompson SG, Deeks JJ, Altman DG: Measuring inconsistency in meta-analyses. BMJ 2003;327:557-560.

11 Yin YD, Zhao F, Ren LL, Song SF, Liu YM, Zhang JZ, Cao B: Evaluation of the Japanese Respiratory Society guidelines for the identification of Mycoplasma pneumoniae pneumonia. Respirology 2012;17:1131-1136.

12 Cao B, Ren LL, Zhao F, Gonzalez R, Song SF, Bai L, Yin YD, Zhang YY, Liu YM, Guo P, Zhang JZ, Wang JW, Wang C: Viral and $M y$ coplasma pneumoniae community-acquired pneumonia and novel clinical outcome evaluation in ambulatory adult patients in China. Eur J Clin Microbiol Infect Dis 2010;29:14431448.

13 Wiemken T, Peyrani P, Bryant K, Kelley RR, Summersgill J, Arnold F, Carrico R, McKinney WP, Jonsson C, Carrico K, Ramirez J: Incidence of respiratory viruses in patients with community-acquired pneumonia admitted to the intensive care unit: results from the Severe Influenza Pneumonia Surveillance (SIPS) project. Eur J Clin Microbiol Infect Dis 2013; 32:705-710.

14 Viasus D, Marinescu C, Villoslada A, Cordero E, Galvez-Acebal J, Farinas MC, GraciaAhufinger I, Fernandez-Navarro A, Niubo J, Ortega L, Munez-Rubio E, Romero-Gomez MP, Carratala J: Community-acquired pneumonia during the first post-pandemic influenza season: a prospective, multicentre cohort study. J Infect 2013;67:185-193.
15 Takahashi K, Suzuki M, Minh le N, Anh NH, Huong LT, Son TV, Long PT, Ai NT, Tho le $\mathrm{H}$, Morimoto K, Kilgore PE, Anh DD, Ariyoshi K, Yoshida LM: The incidence and aetiology of hospitalised community-acquired pneumonia among Vietnamese adults: a prospective surveillance in central Vietnam. BMC Infect Dis 2013;13:296.

16 Musher DM, Roig IL, Cazares G, Stager CE, Logan N, Safar H: Can an etiologic agent be identified in adults who are hospitalized for community-acquired pneumonia: results of a one-year study. J Infect 2013;67:11-18.

17 Huijskens EG, van Erkel AJ, Palmen FM, Buiting AG, Kluytmans JA, Rossen JW: Viral and bacterial aetiology of community-acquired pneumonia in adults. Influenza Other Respir Viruses 2013;7:567-573.

18 Sangil A, Calbo E, Robles A, Benet S, Viladot ME, Pascual V, Cuchi E, Perez J, Barreiro B, Sanchez B, Torres J, Canales L, De Marcos JA, Garau J: Aetiology of community-acquired pneumonia among adults in an H1N1 pandemic year: the role of respiratory viruses. Eur J Clin Microbiol Infect Dis 2012;31:27652772.

Choi SH, Hong SB, Ko GB, Lee Y, Park HJ, Park SY, Moon SM, Cho OH, Park KH, Chong YP, Kim SH, Huh JW, Sung H, Do KH, Lee SO, Kim MN, Jeong JY, Lim CM, Kim YS, Woo JH, Koh Y: Viral infection in patients with severe pneumonia requiring intensive care unit admission. Am J Respir Crit Care Med 2012;186:325-332.

20 Cilloniz C, Ewig S, Ferrer M, Polverino E, Gabarrus A, Puig de la Bellacasa J, Mensa J, Torres A: Community-acquired polymicrobial pneumonia in the intensive care unit: aetiology and prognosis. Crit Care 2011; 15:R209.

-21 Shibli F, Chazan B, Nitzan O, Flatau E, Edelstein H, Blondheim O, Raz R, Colodner R: Etiology of community-acquired pneumonia in hospitalized patients in northern Israel. Isr Med Assoc J 2010;12:477-482.

22 Mermond S, Berlioz-Arthaud A, Estivals M, Baumann F, Levenes H, Martin PM: Aetiology of community-acquired pneumonia in hospitalized adult patients in New Caledonia. Trop Med Int Health 2010;15:1517-1524.

23 Lieberman D, Shimoni A, Shemer-Avni Y, Keren-Naos A, Shtainberg R: Respiratory viruses in adults with community-acquired pneumonia. Chest 2010;138:811-816.

24 Diederen BM, Van Der Eerden MM, Vlaspolder F, Boersma WG, Kluytmans JA, Peeters MF: Detection of respiratory viruses and Legionella spp by real-time polymerase chain reaction in patients with community acquired pneumonia. Scand J Infect Dis 2009;41:4550.

25 Johnstone J, Majumdar SR, Fox JD, Marrie TJ: Viral infection in adults hospitalized with community-acquired pneumonia: prevalence, pathogens, and presentation. Chest 2008;134:1141-1148.
26 Jennings LC, Anderson TP, Beynon KA, Chua A, Laing RT, Werno AM, Young SA, Chambers ST, Murdoch DR: Incidence and characteristics of viral community-acquired pneumonia in adults. Thorax 2008;63:42-48.

27 Charles PG, Whitby M, Fuller AJ, Stirling R, Wright AA, Korman TM, Holmes PW, Christiansen KJ, Waterer GW, Pierce RJ, Mayall BC, Armstrong JG, Catton MG, Nimmo GR, Johnson B, Hooy M, Grayson ML: The etiology of community-acquired pneumonia in Australia: why penicillin plus doxycycline or a macrolide is the most appropriate therapy. Clin Infect Dis 2008;46:1513-1521.

28 Angeles Marcos M, Camps M, Pumarola T, Antonio Martinez J, Martinez E, Mensa J, Garcia E, Penarroja G, Dambrava P, Casas I, Jimenez de Anta MT, Torres A: The role of viruses in the aetiology of community-acquired pneumonia in adults. Antivir Ther 2006;11:351-359.

29 Templeton KE, Scheltinga SA, van den Eeden WC, Graffelman AW, van den Broek PJ, Claas EC: Improved diagnosis of the etiology of community-acquired pneumonia with realtime polymerase chain reaction. Clin Infect Dis 2005;41:345-351.

30 Macfarlane J, Holmes W, Gard P, Macfarlane R, Rose D, Weston V, Leinonen M, Saikku P, Myint S: Prospective study of the incidence, aetiology and outcome of adult lower respiratory tract illness in the community. Thorax 2001;56:109-114.

-31 Luchsinger V, Ruiz M, Zunino E, Martinez MA, Machado C, Piedra PA, Fasce R, Ulloa MT, Fink MC, Lara P, Gebauer M, Chavez F, Avendano LF: Community-acquired pneumonia in Chile: the clinical relevance in the detection of viruses and atypical bacteria. Thorax 2013;68:1000-1006.

32 Saito A, Kohno S, Matsushima T, Watanabe A, Oizumi K, Yamaguchi K, Oda H: Prospective multicenter study of the causative organisms of community-acquired pneumonia in adults in Japan. J Infect Chemother 2006;12:63-69.

33 Van der Sluijs KF, van der Poll T, Lutter R, Juffermans NP, Schultz MJ: Bench-to-bedside review: bacterial pneumonia with influenza pathogenesis and clinical implications. Crit Care 2010;14:219.

34 Wunderink RG: Influenza and bacterial pneumonia - constant companions. Crit Care 2010;14:150.

35 McCullers JA: Insights into the interaction between influenza virus and pneumococcus. Clin Microbiol Rev 2006;19:571-582.

36 Finelli L, Fiore A, Dhara R, Brammer L, Shay DK, Kamimoto L, Fry A, Hageman J, Gorwitz $\mathrm{R}$, Bresee J, Uyeki T: Influenza-associated pediatric mortality in the United States: increase of Staphylococcus aureus coinfection. Pediatrics 2008; 122:805-811.

37 Reed C, Kallen AJ, Patton M, Arnold KE, Farley MM, Hageman J, Finelli L: Infection with community-onset Staphylococcus aureus and influenza virus in hospitalized children. Pediatr Infect Dis J 2009;28:572-576.
Viral Infections in Adult Patients with CAP 
38 Seki M, Kosai K, Yanagihara K, Higashiyama Y, Kurihara S, Izumikawa K, Miyazaki Y, Hirakata Y, Tashiro T, Kohno S: Disease severity in patients with simultaneous influenza and bacterial pneumonia. Intern Med 2007; 46:953-958.

- 39 Nascimento-Carvalho CM, Ribeiro CT, Cardoso MR, Barral A, Araujo-Neto CA, Oliveira JR, Sobral LS, Viriato D, Souza AL, Saukkoriipi A, Paldanius M, Vainionpaa R, Leinonen $\mathrm{M}$, Ruuskanen O: The role of respiratory viral infections among children hospitalized for community-acquired pneumonia in a developing country. Pediatr Infect Dis J 2008;27: 939-941.

40 Cevey-Macherel M, Galetto-Lacour A, Gervaix A, Siegrist $C A$, Bille J, Bescher-Ninet $B$, Kaiser L, Krahenbuhl JD, Gehri M: Etiology of community-acquired pneumonia in hospitalized children based on WHO clinical guidelines. Eur J Pediatr 2009;168:1429-1436.
41 Garcia-Garcia ML, Calvo C, Pozo F, Villadangos PA, Perez-Brena P, Casas I: Spectrum of respiratory viruses in children with community-acquired pneumonia. Pediatr Infect Dis J 2012;31:808-813.

42 Esposito S, Daleno C, Prunotto G, Scala A, Tagliabue C, Borzani I, Fossali E, Pelucchi C, Principi N: Impact of viral infections in children with community-acquired pneumonia: results of a study of 17 respiratory viruses. Influenza Other Respir Viruses 2013;7:18-26.

43 Bautista E, Chotpitayasunondh T, Gao Z, Harper SA, Shaw M, Uyeki TM, Zaki SR, Hayden FG, Hui DS, Kettner JD, Kumar A, Lim M, Shindo N, Penn C, Nicholson KG: Clinical aspects of pandemic 2009 influenza A (H1N1) virus infection. N Engl J Med 2010; 362:1708-1719.

44 Furumoto A, Ohkusa Y, Chen M, Kawakami K, Masaki H, Sueyasu Y, Iwanaga T, Aizawa $\mathrm{H}$, Nagatake T, Oishi K: Additive effect of pneumococcal vaccine and influenza vaccine on acute exacerbation in patients with chronic lung disease. Vaccine 2008;26:4284-4289.
45 Yu H, Liao Q, Yuan Y, Zhou L, Xiang N, Huai Y, Guo X, Zheng Y, van Doorn HR, Farrar J, Gao Z, Feng Z, Wang Y, Yang W: Effectiveness of oseltamivir on disease progression and viral RNA shedding in patients with mild pandemic 2009 influenza A H1N1: opportunistic retrospective study of medical charts in China. BMJ 2010;341:c4779.

46 Jokinen C, Heiskanen L, Juvonen H, Kallinen S, Kleemola M, Koskela M, Leinonen M, Ronnberg PR, Saikku P, Sten M, Tarkiainen A, Tukiainen H, Pyorala K, Makela PH: Microbial etiology of community-acquired pneumonia in the adult population of $4 \mathrm{mu}$ nicipalities in eastern Finland. Clin Infect Dis 2001;32:1141-1154.

47 Ishida T, Hashimoto T, Arita M, Ito I, Osawa $\mathrm{M}$ : Etiology of community-acquired pneumonia in hospitalized patients: a 3-year prospective study in Japan. Chest 1998;114:15881593. 